\title{
PREMISES OF SUSTAINABLE DEVELOPMENT CONCEPT OCCURENCE
}

\author{
Elisabeta-Emilia HALMAGHI \\ “Nicolae Bălcescu” Land Forces Academy, Sibiu, Romania \\ emmahalmaghi@gmail.com \\ Mihai-Marcel NEAG \\ “Nicolae Bălcescu” Land Forces Academy, Sibiu, Romania \\ mmneag@yahoo.com
}

\begin{abstract}
It has long been considered that the environment can withstand all the pressure exerted by human activities on it: extensive agriculture, pesticide use, strong industrialization, noxious gas emissions into the atmosphere, toxic product discharge into lakes, rivers, seas and oceans, massive deforestation to obtain new areas for housing or agriculture. The result was environmental and soil degradation, increased water and/or air pollution, climate change, biodiversity loss, the disappearance of plant and/or animal species, the depletion of some natural resources. These environmental changes have begun to be studied by specialists in the field, who have raised a flag to irreversible environmental changes.

The concept of "sustainable development" arose at a time when environmental issues were at the heart of political debate: sustainable development is seen as a complex and difficult issue to solve because there is a diversity of interests of different states. International agreements and cooperation from the point of view of globalization and economic harmonization have also had as their object the issues of sustainable development, by launching the attempt to reconcile the economy with the environment.
\end{abstract}

KEYWORDS: sustainable development, environmental protection, Brundtland Report

\section{Introduction}

Since the 1960s, both scientists in the field of earth sciences or economics, as well as scientific or fiction authors have begun to warn about the state of the environment and the effects of human activities on it. In the 1970s of the same century politicians have also begun to realize that, at that time, economic growth was achieved without any concern in terms of social and environmental objectives. Due to the increase in industrial production, intensive agriculture and population growth in some parts of the globe, the environmental factors have deteriorated.
Initially, the idea of sustainable development has started from the premise that companies can grow economically by protecting the environment. Over time, the concept has undergone changes now reaching three pillars: economic development, social development and environmental protection.

\section{Methodology}

The paper addresses the issue of sustainable development, from the emergence of the concept to the present days, the way in which the definition of sustainable development concept has undergone changes over time. The environment and the need for 
its protection, the reports that led to the emergence of the concept of sustainable development, as well as the most important top-level meetings that had on the agenda, as main topic of debate, sustainable development on the three dimensions: economic, social and environmental are presented and analyzed based on the literature and direct observations.

\section{The Environment and Awareness of the Need for Its Protection}

Initially, since the nineteenth century, the term environment has been used in the biological sense as the natural environment of living creatures and has also been taken up in the field of geography where it has been defined as "living and human-influenced space" (Duţu, 1996, p. 36). As environmental science has developed, various environmental definitions have emerged. In 1972, at the "Enseignement et Environnment" international symposium held in Aix en Provence (France), the concept of the environment was grounded and defined as "the entire physical, chemical, biological, and social aspects existing at one moment, likely to create a direct or indirect effect, immediately or later, on the creatures, the human beings and the human activities" (Oprean \& Suciu, 2003, p. 20).

Although concrete actions - of an economic, legal or institutional nature - to prevent and combat pollution have called for a more precise definition of the concept of environment and its components, the definitions and meanings of the environmental concept are still very varied, depending on the field which defines it. If the definition of the environment from the point of view of natural sciences emphasizes the natural factors and how they influence and/or are influenced by the activity of the people, from the legal perspective the emphasis is on the quality of people's life, on their welfare and health. From an economic point of view, the notion of the environment is much more complex and refers generally to the environment of an organization, to the components that make it up, and to the interdependencies established between those components. An exception is the definition in ISO 14000 - Environmental Management Systems, a definition that refers to biotic and abiotic factors and human beings, as well as relationships that are established between the three elements.

The main effects of human activities on the environment are (Diesendorf, 2001 p. 3): climate change and changes in the composition of the atmosphere; reducing the ozone layer, which increases the negative effects of ultraviolet light on living organisms; soil degradation and increased desertification; decreasing biodiversity; deterioration of photosynthesis cycles and nutrients; large-scale pollution of rivers, lakes, seas and oceans; exhaustion of groundwater reserves. The consequences of human activities and environmental damage are also felt at the society level. With the emergence of pollution and the depletion of natural resources, society has increased social inequality, reduced living conditions in some areas of the globe, increased numbers of people who do not have access to education or do not allow medical treatment, and so on.

The consequences of economic growth could be seen in the depletion of natural resources and the widespread degradation of environmental factors, social injustice between and within societies, the rapid exhaustion of certain energy sources and climate change. As a result, the idea that, economically, socially and ecologically, the economic development models used could not be sustained without the environment having to suffer.

In March 1972 the Club of Rome presented the report drawn up by a group of researchers from the Massachusetts Institute of Technology, coordinated by Professor Dennis Meadows and entitled Growth Limits. In this report five basic factors have 
been analyzed that determine, but also limit, economic growth: population, natural resources, agricultural production, industrial production and pollution. The Limits to Growth have highlighted the contradiction between economic development and the environment: due to the accelerated economic development, environmental factors are physically degraded and polluted, and natural and energy resources are consumed at a rapid pace, which leads to their exhaustion (Meadows, Meadows, Randers \& Behrens III, 1972, pp. 11-12). The report has made politicians and civil society aware of the fact that economic growth issues can not be separated from environmental pollution, population growth or depletion of natural resources.

One first important step towards addressing environmental and social issues was through the organization in June 1972, in Stockholm, of the United Nations Conference on Human Environment. During the conference, issues related to pollution, exhaustion of natural resources, environmental degradation, the danger of the disappearance of some plant and animal species, the need to increase the standard of living of people in deprived areas of the planet. The main document adopted at the conference was the Declaration of the United Nations Conference on Human Environment, based on the premise that "man is both the creator and the destroyer of his environment, provides natural support and gives it the possibility of intellectual, moral, social and spiritual growth” (UN Documents, 1972). The United Nations Environment Program (UNEP) is presented during the conference, based on which the Governing Board and the United Nations Environment Program Secretariat are established in the United Nations General Assembly, in December 1972. In January 1973, the Voluntary Environment Fund (also called the Environmental Fund), which is the main source of funding for the United Nations Environment Program, is set up in accordance with United Nations financial procedures. Contributions are voluntary and all United Nations member states contribute to it. The money obtained is used to implement the programs and the mediumterm strategy.

Within the United Nations, the United Nations Environment Program is the authority that sets the global environmental agenda, militate for the harmonized implementation of the environmental dimension of sustainable development, and can serve as an advocator for environmental issues. Its mission is to ensure the leadership and encouragement of partnerships in the care and protection of the environment through information and assistance to the states of the world and their citizens to improve the quality of their lives without harming the quality of life of future generations (UN Environment Program, 2019).

In the autumn of 1983, the United Nations Environment and Development Commission (WCED) was established, following Resolution no. 38-161 of the General Assembly of the United Nations. The Commission was composed of 22 members representing 21 nations; they had very different professions, knowledge, experiences and cultural traditions, as it was intended to obtain as varied input as to the work of the committee. Concerning the composition of the commission, about half of the members were trying to represent the developing nations. Although initially perceived as a body primarily focused on environmental issues, the commission has shown from the outset that economic development is a key component of its concerns, drawing attention to endemic poverty in many of the third world countries. The Commission's inaugural meeting was held in October 1984 and in a relatively short time (3 years), the Commission concluded the drafting of the report (called the Brundtland Report), which was adopted unanimously, even though on certain issues the members of the committee had different opinions. 


\section{Integrative Approach to the Concept of Sustainable Development}

The concept of sustainable development was used for the first time in 1981 in the World Conservation Strategy, later being taken over in other United Nations documents, of which the most commonly known is the Brundtland Report (1987). In the Brundtland Report, sustainable development is defined as being "that development that meets the needs of the present without compromising the ability of the next generation to meet its own needs" (Report of the WCED, 1987, p. 41). This approach implies a reorientation of public policies to determine "a process of change in which resource exploitation, investment direction, technological development orientation, and institutional change are all in harmony and increasing both current and future potential to meet the human needs and aspirations" (Report of the WCED, 1987, p. 46).

The idea from which sustainable development started to be define from shows that it can progress economically and socially without the natural balance of the Earth being jeopardized. The concept of sustainable development was considered to be the result of an integrated approach, in which "environmental protection and longterm economic growth are considered complementary and mutually dependent" (SNDDR, 2008).

Sustainable development means ensuring a balance between environmental protection and economic growth by:

a) increasing the quality of people's lives in terms of meeting primary needs and reducing uncontrolled demographic growth;

b) reshaping economic growth taking into account the most efficient and fair use of the available resources to obtain high quality products with minimal and nontoxic waste;

c) preserving the quality of the environment and natural resources; d) firm ownership of governance bodies in decision-making on the economy and the environment (Antonescu, 2011, pp. 79-80).

More than 60 definitions of sustainable development have been formulated so far, all of which share the economic, social, ecological/environmental components, but also two key parameters: maintaining economic growth without affecting the environment and neglecting the most important environment, above all economic development and society. The most well-known and representative definition remains the one in the Brundtland Report, which states that each generation has the right to develop economically, socially, demographically within the limits of its resources, because future generations are not obliged to "pay" for the development of the previous generation. That is why the present generation has the obligation not to leave future generations without resources: economic (through the obligation to pay the debts of the past generation), social (by lowering investments in education and training due to the poor financial situation left by the past generation), demographic (through uncontrolled growth of the past generation population) or environmental (through the decrease or depletion of natural resources, but also the pollution of the environment by the last generation).

The Brundtland Report also includes some objectives according to which the implementation of sustainable development means (Pohoață, 2015, p. 15):

a) ensuring economic growth while respecting the minimum conditions for the preservation and protection of natural resources;

b) decreasing/eliminating poverty and providing favorable conditions to meeting the living needs: food, water, workplace, living space, energy, health;

c) controlled population growth in the world; 
d) preserving and increasing renewable natural resources by reducing the negative effects of economic development on environmental factors;

e) using less polluting new technologies and the risk of which can be kept under control;

f) integrated approach to decisions on economic growth, the environment and energy resources.

At the end of the Brundtland Report, the idea was maintained that an international meeting was to be held with the main theme of sustainable development. This meeting was held in June 1992, in Rio de Janeiro, when they hosted UN Conference on Environment and Development or the Earth Summit (UNCED Conference, 1992). On this occasion, the concept of sustainable development was accepted and adopted and the need to integrate economic development and environmental protection into the objective of sustainable development was acknowledged. The importance of international environmental law as a codification and promotion mechanism for sustainable development was also stated.

Due to the size and scope of its concerns, the Earth Summit was considered the largest summit meeting. It was also the first Summit at which the United Nations tried to help governments find ways to reduce pollution of environmental factors without giving up economic and social development (UNCED Conference, 1992).

The works of the conference highlighted the paradoxes of contemporary society: both gaps and poverty, and excessive consumption, cause the deterioration of the environment and only by transforming the attitudes and behaviour of the planet's inhabitants will make the necessary changes for a truly sustainable development. The Earth Summit influenced all subsequent United Nations'conferences focusing on human rights, women's rights, population, human settlements, social development and the need for sustainable ecological development (UNCED Conference, 1992). The results of the meeting materialized in the adoption of the Rio Declaration on Environment and Development, which contains a set of principles defining the rights and responsibilities of the world's states and Agenda 21, a global action program aimed at preparing mankind for the challenges of the next century and includes detailed proposals for action in the economic, social and environmental fields (change of production and consumption patterns, addressing demographic dynamics, combating poverty, conservation and sustainable management of resources, etc.) (Earth Summit, 1992).

Starting with the Earth Summit, the concept of sustainable development becomes even clearer in the context of the coexistence of "human development" and "growth" concepts and will be included in all local or regional development programs. The Rio Conference was followed by other high-level meetings where issues related to the need to protect environmental factors, economic and social development, climate or forest changes were discussed. Among these are: Earth Summit 2002 (Johannesburg 2002), Copenhagen Climate Change (2009), Rio+20 Earth Summit (Rio de Janeiro, 2012), Warsaw Climate Change Conference (November 2013), (Moşteanu, Muscalu, Todericiu \& Halmaghi, 2015, p. 15).

In June 1997, the United Nations General Assembly Special Session in New York examined the progress made in the five years since the Earth Summit. As several deficiencies have been highlighted, mainly related to social equity and poverty, and the objectives of the Summit have not been met, it is decided to establish another special session of the United Nations General Assembly to adopt the political instruments and the necessary mechanisms to ensure the achievement of the Rio objectives in 1992. 
In September 2000, the Millennium Summit takes place in New York, where the UN Millennium Declaration was adopted, through which the world's states committed themselves to a new global partnership aimed at reducing extreme poverty. Also, at the Summit a series of objectives were proposed with an impact on the national and international sustainable development strategies, known as the Millennium Development Goals (Millennium Summit, 2000), which had a final deadline the year 2015. Between 2000 and 2015, remarkable progress has been made in meeting the proposed indicators, which has led to a marked improvement in living conditions for many of the world's poorest people.

The Millennium Summit was followed in 2002 by the Summit on Sustainable Development held in Johannesburg. The main objective of this Summit was to renew the political commitment to sustainable development and adopted the Johannesburg Declaration on Sustainable Development which strengthened the links between economic development, social development and environmental protection at all levels and the World Summit Implementation Plan on Sustainable Development (Moșteanu et al., 2015).

This Summit confirmed that sustainable development is an important theme of high-level meetings and reaffirmed the need for practical implementation of global fighting measures for a cleaner environment, reducing poverty and raising living standards for less developed areas. The concept of sustainable development has been deepened and strengthened by highlighting strong links between the environment, people's poverty, economic development and the efficient use of natural resources.

In 2012 in Rio de Janeiro held the United Nations Conference on Sustainable Development, with the topic The Future We Want. Starting from the premise that the objectives of the Rio de Janeiro conference in 1992 were not achieved, the conference had three objectives (Leggett \& Carter, 2012):

- the renewal of the political commitment to the sustainable development of the world's states;

- assessing the progress made and the shortcomings in the implementation of the results of previous summits that have been debated on sustainable development;

- addressing new environmental challenges.

Discussions held at the conference focused on two important themes (Leggett \& Carter, 2012):

a) Green economy as part of sustainable development and poverty eradication. Although it was an important point of discussion, there was no agreement on what the green economy is and what its relationship with sustainable development is. If in 1992 at the Earth Summit, sustainable development was described as being made up of three dimensions: economic development, social development and environmental protection, in 2012 the Green Economy was considered to be the "intersection of the environment and the economy" and is a pillar of sustainable development. There have been voices that have criticized the fact that the emphasis is too much on the economy to the detriment of society, which has the consequence of replacing the concept of the three pillars/dimensions that form sustainable development;

b) Institutional Framework for Sustainable Development (IFSD). Many stakeholders agreed that a reform of existing international processes and institutions with environmental concerns would increase the efficiency and effectiveness of environmental protection. There was also a general consensus on the need for high-level intergovernmental bodies on sustainable development.

United Nations Member States, aware that after 2015 when the Millennium 
Development Goals have a deadline for completion, a new Development Agenda is needed, they have decided to adopt a set of 17 Sustainable Development Objectives that have based on the Millennium Development Goals and have the same purpose as the post2015 development agenda (UNCSD, Rio+20, 2012). The final document of the Rio+20 Conference acknowledged the need to further integrate sustainable development at all levels and called for the integration of the three dimensions of sustainable development into the United Nations system, calling for progress to be reported in this regard.

In September 2015, the United Nations Summit on Sustainable Development, which had as its main objective the post-2015 development agenda, was held in New York. The final document adopted was Agenda 2030 for Sustainable Development, which is "a global action program in the field of universal development and promoting the balance between the three dimensions of sustainable development - economic, social and environmental" (Ministry of Foreign Affairs - MAE, 2015) and "the first global agreement to establish a comprehensive agenda of universal action that will influence all countries, including their internal policies" (European Commission, 2015).

Agenda 2030 includes 17 Sustainable Development Objectives and 169 targets, being for the first time when actions to be taken globally also address both developing and developed countries. Objectives and targets will stimulate action in areas of great importance for humanity and the planet over the next 15 years, ensuring the balance between the three dimensions of sustainable development: economic, social, environmental protection. Areas of action will be: poverty, inequality, health, water and sanitation, famine and food security, energy, sustainable consumption and production, growth, employment, infrastructure and industrialization, sustainable management of natural resources, oceans, biodiversity, forests and desertification, climate change, but also education, gender equality, peaceful and inclusive societies, inequity, access to justice and responsible institutions.

\section{Conclusions}

The concept of sustainable development is a complex concept of reconciliation between the economy and the environment and is based on both the three pillars: economic development, social development, environmental protection and cultural components, and security at national, regional and/or international level. This approach seeks to interact with three systems: economic, human, environmental. Sustainable development can be achieved at any level, provided that a balance is kept between the need for development and the real possibilities for development.

Sustainable development is currently pursuing, alongside environmental issues, the eradication of poverty and hunger; access to the sanitary system; access to quality education; reducing pollution of environmental factors; decreasing the migration of the inhabitants of the poor states of the world or those affected by the wars; eliminating as far as possible job insecurity and creating decent jobs; the controlled expansion of urbanization, focusing on building sustainable cities.

Sustainable development requires strategies on short and medium time horizons, which can be addressed in the long term for up to 25 years. This requires environmental, economic and social policies, both at national and international level. It is imperative that these policies have clear objectives, criteria for assessing their fulfilment, as well as legal, economic and social key factors.

\section{Acknowledgement}

This article is part of the research for the $\mathrm{PhD}$ thesis on the Influence of Organizational Culture on Organizational Behavior in Sustainable Development Management. 


\section{REFERENCES}

Antonescu, D. (2011). Dezvoltarea regională. Tendinţe. Mecanisme. Instituţii. Bucureşti: Top Form.

Diesendorf, M. (2001). Sustainability and Sustainable Development, available at: https://www.researchgate.net/publication/5171554_Models_of_sustainability_and_sustainable development, accessed on 10 January 2019.

Division for Sustainable Development Goals, Department of Economic and Social Affairs, United Nations Secretariat Building. (2012). United Nations Conference on Sustainable Development Rio+20, available at: https://sustainabledevelopment.un.org/rio20, accessed on 15 January 2019.

Duţu, M. (1996). Dreptul mediului. Bucureşti: Economică.

Earth Summit (1992). United Nations Conference on Environment and Development (UNCED). Rio de Janeiro, Brazilia, available at: http://www.un.org/geninfo/bp/enviro.html, accessed on 10 January 2019.

Earth Summit - Background (1992), available at: http://www.un.org/geninfo/ bp/envirp2.html, accessed on 12 January 2019.

European Commission Press Release Database. (2015). Comisia Europeană salută noua Agendă 2030 a Organizaţiei Naţiunilor Unite pentru dezvoltare durabilă, available at: http://europa.eu/rapid/press-release_IP-15-5708_ro.htm, accessed on 12 January 2019.

Guvernul României, Ministerul Afacerilor Externe (2017). O nouă Agendă pentru dezvoltare durabilăa, available at: https://www.mae.ro/node/35919\#null, accessed on 15 January 2019.

Guvernul României, Ministerul Mediului şi Dezvoltării Durabile. (2008). Strategia Naţională pentru Dezvoltare Durabilă a României Orizonturi 2013-2020-2030. Bucureşti, available at: http:// www.mmediu.ro/ beta/ wp-content/ uploads/ 2012/ 06/ 2012-0612_dezvoltare_durabila_snddfinalromana2008.pdf, accessed on 15 January 2019.

Leggett, J. A., \& Carter, N. T. (2012). Rio+20: The United Nations Conference on Sustainable Development. Congressional Research Service, available at: https:// fas.org /sgp/ crs/row/R42573.pdf, accessed in 12 January 2019.

Meadows, D. H., Meadows, D. L., Randers, J., \& Behrens III, W.W. (1972). The Limits to Growth. A Report for the Club of Rome's Project on the Predicament of Mankind, available at: $\quad$ www.donellameadows.org/wp-content/userfiles/Limits-to-Growth-digital-scan-version. pdf, accessed on 09 January 2019.

Moşteanu, D., Muscalu, E., Todericiu, R., \& Halmaghi, E. E. (2015). Dezvoltare durabilă. Sibiu: Editura Academiei Forţelor Terestre "Nicolae Bălcescu".

Oprean, C., \& Suciu, O. (2003). Managementul calităţii mediului. Bucureşti: Editura Academiei Române.

Pohoaţă, I. (2015). Strategii şi politici europene de dezvoltare durabilă. Iaşi: Universitatea "Alexandru Ioan Cuza", Centrul de Studii Europene, available at: www.cse.uaic.ro/_fisiere/Documentare/Suporturi_curs/II_Strategii_si_politici_europene_de_d ezvoltare_durabila.pdf, accessed on 10 January 2019.

Report of the World Commission on Environment and Development: Our Common Future, available at: https://sustainabledevelopment.un.org/content/documents/5987ourcommon-future.pdf, accessed on 15 January 2019. 
The United Nations Environment Programme. (1987). About UN Environment, available at: https://www.unenvironment.org/about-un-environment, accessed on 10 January 2019.

UN Documents - Declaration of the United Nations Conference on the Human Environment. (1972), available at: un-documents.net/unchedec.htm, accessed on 09 January 2019.

United Nations, Conferences, Meetings and Events. (2000). Millenium Summit, available at: http://www.un.org/en/events/pastevents/millennium_summit.shtml, accessed on 12 January 2019. 